\title{
Pharmaceutical Industrial Waste Regulation in Five Countries in Asia
}

\author{
Luthfia Azzahra $^{1^{*}}$, Nyi Mekar Saptarini² \\ ${ }^{1}$ Apothecary Programme, Faculty of Pharmacy, Padjadjaran University, Sumedang, Indonesia \\ ${ }^{2}$ Department of Pharmaceutical Analysis and Medicinal Chemistry, Faculty of Pharmacy, \\ Padjadjaran University, Sumedang, Indonesia
}

Received: 14 Jan 2021, Revised: 16 Feb 2021, Accepted: 28 Feb 2021, Published: 1 March 2021

\begin{abstract}
The pharmaceutical industry produces a various toxic wastes. Generated waste increases the risk of environmental and ecosystem pollution. It is necessary to have proper waste management to prevent waste pollution to the environment. In 1999, WHO published "Guidelines for the Safe Disposal of Unwanted Pharmaceuticals in and after Emergencies", that contain treatments and safe disposal method, which is appropriate for any country. Many countries had developed and published regulations and guidelines on waste management. This article aimed to review the handling of pharmaceutical industrial waste in five countries in Asia. This review included studies from ProQuest, Crossref, and Google Scholar. The pharmaceutical industries in Indonesia, India, Japan, Thailand, and China has their own state regulations in order to protect the environment. They also had implemented pharmaceutical industrial waste management following their regulation and guidelines. The method used to treat the waste is similar with WHO guideline. Some factors affecting the country regulations are the insufficient of land and waste management facilities, lack of awareness, low penalties, limited infrastructures, lack of waste testing facilities. The challenge in the future to handle pharmaceutical waste are increasing waste volume, decreasing land for waste management, sewer methods may contaminate water, possible air pollution due to incineration, so it is necessary to have more advanced methods in waste management that are safe for the environment and humans.
\end{abstract}

Keyword: Industry, Pharmaceutical, Waste Regulation, Asia

\section{Introduction}

The pharmaceutical industries produce hazardous and toxic waste, which contains organic and inorganic compounds derived from the formulation process of pharmaceutical products, the washing process of production equipment, laboratory activities, and product residues which out of specifications (1). Pharmaceutical industrial waste produced is various, it can be in the form of acid, alkaline, salt, and potentially toxic residues or solvents, furthermore, pharmaceutical industrial products, such as antibiotics can cause bacterial resistance (2).

Industrial waste has the risk of damaging the environment and the ecosystem. Therefore, it is necessary to have proper waste management to prevent harmful impacts on the product, 
human, environment, and ecosystem. There are mainly four types of industrial waste, i.e. solid waste, liquid waste, air pollution, and sound pollution. WHO published "Guidelines for the Safe Disposal of Unwanted Pharmaceuticals in and after Emergencies" in 1999. This guideline consists of particular attention to how pharmaceutical wastes are disposed, including incineration, landfill, encapsulation, sewer, and chemical decomposition. The guidelines outline a variety of strategies for disposing of pharmaceuticals safely. There are approaches that carry the smallest risks to public health and the environment, including those that are appropriate for countries with limited resources and equipment. The WHO guidelines recommend a range of slightly less-safe treatments and disposal methods, when weighed against the risks of excessive or nondisposal, are appropriate to relative risk (3).

Some countries with limited resource and/or equipment still has some problem, for example in Indonesia, there are still unsupervised open burning site that pollutes air (4). In India where there are still illegal waste management practices that pollute the air and water due to lack of supervision and the lack of land provision $(5,6,7)$. In Thailand, poor waste material handling, the lack of land provision led to environment pollution such as leachate and hazardous waste $(8,9,10,11)$. This affects each country regulation and additional requirements of waste management. Due to the problems mentioned above, it is important to adopt alternative strategies, to ensure that municipalities play their role correctly, to ensure that government fulfil their roles and responsibilities on waste management, and to give penalties to those who violate the regulations. $(4,12)$.

Pharmaceutical industrial waste is one of the alarming issues. Many countries had developed and published guideline on how to handle pharmaceutical waste. This article reviews the handling of pharmaceutical industrial waste in five countries in Asia namely Indonesia, India, Japan, Thailand, and China. These five countries were chosen to see differences in the management of pharmaceutical waste in countries with different industrial developments.

\section{Method of Article Searching}

This review included regulations, guidelines and articles from ProQuest, Crossref, and Google Scholar. Keywords were used to find articles was "pharmaceutical industrial waste" OR "pharmaceutical waste", AND "asia” OR "asean". Inclusion criteria were used as mentioned on flowchart. Systematic reviews and unrelated studies such as incomplete sources and non-pharmaceutical waste studies were all excluded from the study.

\section{Results and Discussion}

Table 1. Articles Searching Results

\begin{tabular}{ccc}
\hline $\begin{array}{c}\text { Search } \\
\text { engine }\end{array}$ & $\begin{array}{c}\text { Number of } \\
\text { Articles }\end{array}$ & $\begin{array}{c}\text { Articles used } \\
\text { for review (n) }\end{array}$ \\
\hline ProQuest & 247 & 5 \\
\hline $\begin{array}{c}\text { Google } \\
\text { Scholar }\end{array}$ & 863 & 15 \\
\hline Crossref & 370 & 11 \\
\hline
\end{tabular}

From the article searching results, it was found that five countries in Asia had sufficient information. The information includes the regulation and handling of their pharmaceutical industry waste, passed the screening, and fit into the inclusion criteria. The process of waste management based on the WHO's guideline on handling waste which is used as a reference by countries (3):

\section{1) Chemical disinfection}

Liquid wastes are best treated with chemical disinfection. Chemical disinfection may also be used to destroy or inactivate bacteria in waste, microbiological cultures, mutilated sharps, or shredded solids by adding powerful oxidants, such as chlorine compounds, ammonium salts, aldehydes, or phenol compounds. The type and 
amount of chemical used, as well as the degree and length of contact between the disinfectant and the waste, all affect disinfection performance $(3,13)$

Sources identified from Google Scholar, Proquest, Crossref $(\mathrm{n}=1480)$

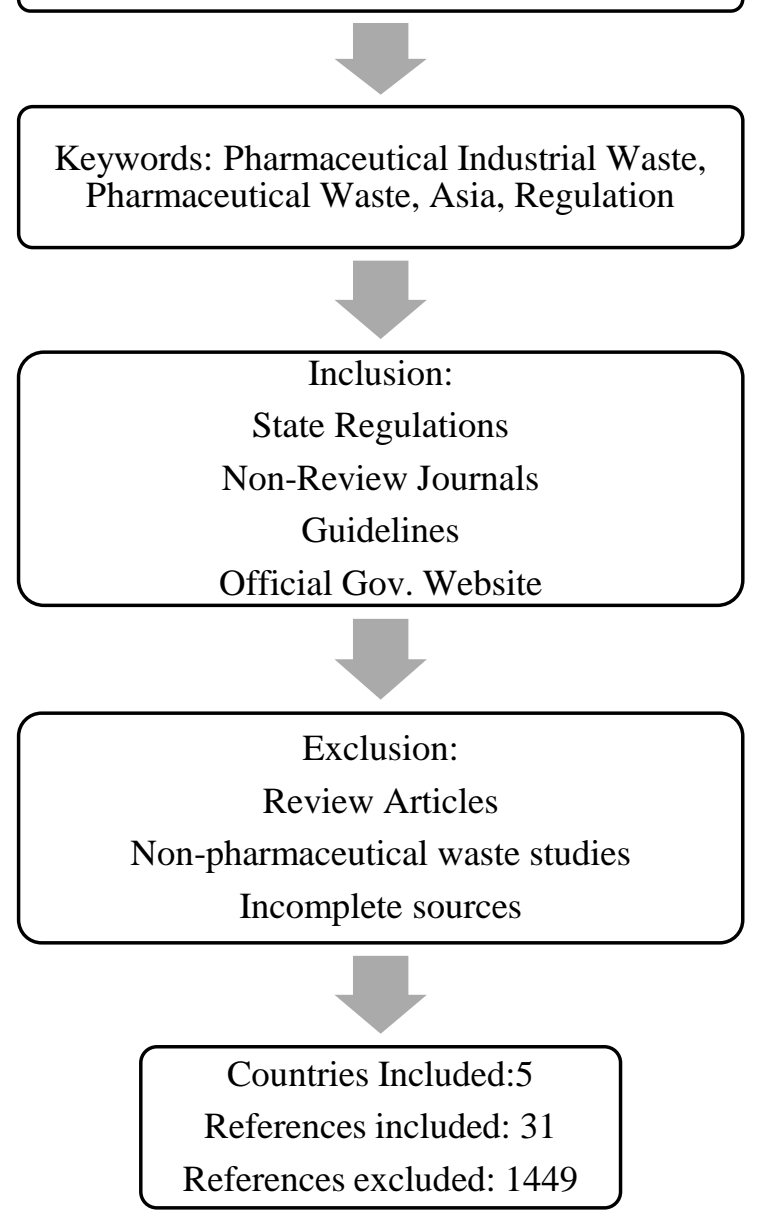

Figure 1. Flowchart of Methodology

\section{2) Secure land filling}

Secure land filling is the process of disposing of solid wastes in a landfill that is specifically built and managed to handle hazardous wastes. In most countries, burying waste in a landfill is still the standard method of waste disposal. In abandoned or unused quarries, mining voids, and borrow pits, landfills were frequently created. A well-designed and well-managed landfill can be a sanitary and relatively inexpensive way to dispose of waste. A modern landfill's design features include methods for containing leachate, such as clay or plastic lining content. Waste is compacted and coated to maximize its density and stability and to deter vermin (mice or rats) from attracting it (3).

\section{3) Inertization}

Inertization is a form of encapsulation that involves removing the packaging materials from the pharmaceuticals, such as paper, cardboard, and plastic. The blister packs of pills must be withdrawn. After that, the wastes are ground and mixed with water, cement, and lime to make a homogeneous paste. The paste is then transported to a landfill in a liquid condition by a concrete mixer truck and decanted into regular municipal waste. The paste then solidifies into a solid mass that is spread throughout municipal solid waste. The procedure is relatively low-cost and can be completed with basic equipment $(3,13)$

\section{4) Sewer}

Any liquid pharmaceuticals, such as syrups and intravenous fluids, may be diluted with water and flushed into sewers in limited amounts over time without causing damage to public health or the environment. Tiny amounts of welldiluted liquid pharmaceuticals or antiseptics may also be flushed by fast-flowing watercourses (3).

\section{5) Incineration}

Incineration is a waste disposal process that involves combusting solid organic wastes to produce residue and gaseous materials. This method can be used to dispose of solid waste management residue as well as solid waste management residue from waste water management. It can be carried out on a small and large scale. It is accepted as a viable method of disposing of such hazardous wastes. Due to concerns such as the release of gaseous emissions, incineration is a contentious waste disposal process. Ash from these incinerators must be disposed of in a secure landfill $(3,13)$ 
Table 2. Summary of Waste Management Methods

\begin{tabular}{|c|c|c|c|c|}
\hline No. & Method & Advantage & Suitability & Reference \\
\hline 1. & Chemical disinfection & $\begin{array}{l}\text { Efficient and drastic reduction in } \\
\text { waste volume }\end{array}$ & $\begin{array}{l}\text { Liquid and } \\
\text { solid waste }\end{array}$ & $(3,13)$ \\
\hline 2. & Secure land filling & Relatively simple & Solid waste & $(3,13)$ \\
\hline 3. & Inertization & Relatively inexpensive & $\begin{array}{lr}\text { Waste } & \text { with } \\
\text { high } & \text { metal } \\
\text { content } & \\
\end{array}$ & $(3,13)$ \\
\hline 4. & Sewer & Practical and easy & Liquid waste & $(3,13)$ \\
\hline 5 . & Incineration & $\begin{array}{l}\text { Drastic reduction in waste } \\
\text { volume, efficient }\end{array}$ & Solid waste & $(3,13)$ \\
\hline 6. & Encapsulation & relatively cheap, simple, and safe & Solid waste & $(3,13)$ \\
\hline 7. & Deep burial & $\begin{array}{l}\text { Low cost and safe (in restricted } \\
\text { area) }\end{array}$ & Solid waste & $(3,13)$ \\
\hline 8. & Autoclaving & Low cost and efficient & Solid waste & $(3,13)$ \\
\hline 9. & Microwaving & Good disinfection efficiency & liquid waste & $(3,13)$ \\
\hline
\end{tabular}

6) Encapsulation

The wastes are immobilized in a solid block inside a plastic or steel drum during encapsulation. They are filled to $75 \%$ capacity with solid and semi-solid waste, with the remaining space filled with cement, cement/lime mixture, plastic foam, or bituminous sand. After the drums have been filled to $75 \%$ capacity, a 15:15:5 (by weight) mixture of lime, cement, and water is applied and the drum is filled to capacity $(3,13)$.

There are other methods apart from the WHO guideline that is used by five countries which reviewed in this article $(14,15,16)$ :

\section{7) Deep burial}

The deep burial site should be prepared by digging a 2-meter deep pit or trench in a location that is not vulnerable to flooding or erosion, where the soil is relatively impermeable. There are no nearby residents or shallow wells, and the possibility of surface water pollution is minimal $(3,13)$.

\section{8) Autoclaving}

Autoclaves are used to sterilize products, due to saturated steam in direct contact with the product in a pressure vessel for long enough periods of time and at high enough temperatures to destroy pathogens. Before autoclaving, it is required shredding the waste to an acceptable size which is an operation that would involve frequent breakdown for waste handling purposes. Autoclaving generates a waste stream that can be used to fill landfills with municipal waste. Autoclave operation requires qualified technicians, and medium investment and operating cost $(3,13)$.

\section{9) Microwaving}

Microwaves use an electric field to induce liquid in the waste to oscillate and heat up, killing infectious components by conduction. The waste material has to be exposed to ultraviolet radiation for this technology to be useful in order to destroy pathogens (17). The waste must be shred to an appropriate size and humidified before being microwaved. Microwaving generates waste that can be used to fill landfills $(3,13)$.

The waste management and procedure in each country are similar to WHO. As for the regulation for each country are slightly different as discussed below. 


\section{Indonesia}

Waste handling is a critical matter in the pharmaceutical industry which must be considered, managed properly, and reported to the competent authority, i.e. the Ministry of Environment and the Environmental Service. Waste which managed properly can protect the environment, personnel, and the quality of products produced by the pharmaceutical industry. Therefore, the pharmaceutical industry is obliged to handle and inspect waste so that the waste produced by the pharmaceutical industry meets the environmental quality standards set by the Ministry of Environment. There are several regulations governing industrial waste handling in Indonesia, especially pharmaceutical industrial waste (Table 3). The techniques used in order to handle the waste are similar to the WHO guideline. In Indonesia, pharmaceutical industry waste management is generally carried out by autoclaving, incinerators, microwave irradiation, chemical disinfection, sewer, encapsulation, inertization and safe burial/landfilling. For liquid waste, many pharmaceutical industries use wastewater treatment plant. The WHO guideline is quite relevant and all methods are suitable to be applied in Indonesia but still need improvement on discipline and supervising, it also need to develop new methods (18).

In the regulations, there are requirements that must be met before the processed waste can be disposed to the environment. Pharmaceutical industries in Indonesia are required to report the results of waste management inspections to the authorities regularly.

In the Regulation of the State Minister for the Environment of the Republic of Indonesia Number 16 of 2012 Article 2 paragraph (2) it is stated that the AMDAL, UKL-UPL and SPPL are "Environmental Documents." Analisis Dampak Lingkungan (AMDAL) or Environmental Impact Analysis is a study of the significant impacts of a business and / or activity on the environment which is required for the decision-making process regarding the operation of a business and/or activity. Upaya Pengelolaan Lingkungan Hidup dan Upaya Pemantauan Lingkungan Hidup (UKL-UPL) or Environmental Management Efforts and Environmental Monitoring Efforts are management and monitoring of businesses and / or activities that do not have a significant impact on the environment required for the decision-making process regarding the operation of a business and/or activity. Surat Pernyataan Pengelolaan Lingkungan (SPPL) or Environmental Management Statement Letter, is a form of commitment of business and/or activity organizers to monitor and manage the environment on the environmental impacts of their business and/or activities outside of businesses and/or activities that are mandatory for AMDAL or UKL-PKL. Industries with large and Significant Impacts must prepare AMDAL, industries with Environmental Impacts must prepare UKL-UPL $(20,21)$.

\section{India}

India is recognised as one of the most fastgrowing pharmaceutical industry globally. India contributes $2.4 \%$ in terms of value and $10 \%$ in terms of quantity internationally. India accounts for $20 \%$ of global exports in generics. In 2016, the Indian pharmaceutical industry exported USD 16.89 billion and is expected to touch USD 40 billion by 2020 (22). Along with the increased pharmaceutical industry in India, so the amount of waste generated is bound to increase. In India, the handling of pharmaceutical waste generated has been regulated since 1995 by Ministry of Environment and Forests, Government of India framed rules for managing Biomedical wastes. The Biomedical Waste (Handling and Management) Rules were published by India's Ministry of Environment and Forests in 1998 $(14,15)$.

India's Ministry of Environment and Forests issued the Biomedical Waste (Handling and 
Management) Rules in 1998 which has been amended twice in 2000. The rules divide biomedical waste into ten groups, each with its own care and control requirements.

Table 3. Indonesia's Regulation on waste handling (19)

\begin{tabular}{cl}
\hline Published Year & \multicolumn{1}{c}{ Regulation } \\
\hline \multirow{2}{*}{1995} & $\begin{array}{l}\text { Minister of Environment Decree No. 50/MENLH/1995 regarding Odor Level } \\
\text { Quality Standards. Jakarta: Ministry of Environment. }\end{array}$ \\
\hline \multirow{3}{*}{1995} & $\begin{array}{l}\text { Ministry of Environment. 1995. Decree of the State Minister for the } \\
\text { Environment No. 13 of 1995 concerning: Emission Quality Standards for } \\
\text { Immovable Sources. Jakarta: Ministry of Environment. }\end{array}$ \\
\hline \multirow{2}{*}{2096} & $\begin{array}{l}\text { Decree of the State Minister for the Environment Number: Kep- } \\
\text { 48/Menlh/11/1996 concerning Noise Level Standards. Jakarta: Ministry of } \\
\text { Environment. }\end{array}$ \\
\hline & $\begin{array}{l}\text { Ministry of Environment. 2012. Regulation of the State Minister for the } \\
\text { Environment of the Republic of Indonesia No. 05 of 2012 concerning Types } \\
\text { of Business Plans and / or Activities that Require an Environmental Impact } \\
\text { Analysis. Jakarta: Ministry of Environment. }\end{array}$ \\
\hline \multirow{2}{*}{$\begin{array}{l}\text { Ministry of Environment 2014. Regulation of the Minister of Environment of } \\
\text { the Republic of Indonesia Number 5 of 2014 concerning Wastewater Quality }\end{array}$} \\
Standards. Jakarta: Ministry of Environment.
\end{tabular}

It is stated that the operators must send an annual report to the appropriate authority detailing the amount of waste generated and the methods used to handle it. Each operator is required to keep records on the waste disposal of the wastes, which can be inspected and checked at any time by the authorized authority.

Table 4. India waste regulation (23)

\begin{tabular}{cl}
\hline Year Published & \multicolumn{1}{c}{ Regulation } \\
\hline 1998 & $\begin{array}{l}\text { Bio-Medical Waste (Management \& Handling) notified by Ministry of } \\
\text { Environment \& Forests (amended on 2000) }\end{array}$ \\
\hline 2008 & $\begin{array}{l}\text { Hazardous Waste (Management, Handling \& Transboundary Movement) } \\
\text { (amended on twice on 2009 and twice on 2010) }\end{array}$ \\
\hline 2016 & $\begin{array}{l}\text { Hazardous and other waste (Management and Transboundary Movement) } \\
\text { (amended on 2016, 2017, 2018, and 2019) }\end{array}$ \\
\hline 2016 & Bio-medical waste management rules (amended on 2018 and twice on 2019) \\
\hline
\end{tabular}

Any misfortune related to waste management must be recorded by each operator. According to the India's pharmaceutical waste rule, the handling of pharmaceutical industrial waste implemented in India are incineration, autoclaving, microwaving, chemical disinfection, deep burial, secure land filling, encapsulation, inertization, and sewer $(14,15)$. The WHO guideline is quite relevant and has been applied in India but it still weak of supervision and lack of awareness from the government and the people to treat waste properly (4).

\section{Japan}

Japan started implementing waste management since 1970s. Japan's regulations on handling waste are stated in Table 5.

Since the 1970s, Nippon Keidanren has continuously promoted CSR as an essential component of Japanese corporate management. 
Keidanren created a Corporate Behavior Charter in 1991 and recently issued CSR guidance. CSR requires all businesses to adhere to its standards and file an annual report on Resource Conservation and Waste Management. The Federation of
Pharmaceutical Manufacturers Associations of Japan (FPMAJ) is a trade association that represents pharmaceutical manufacturers in Japan. They investigate waste management practices in Japanese pharmaceutical firms.

Table 5. Japan's Early Regulation on Waste Handling (24, 25, 26)

\begin{tabular}{cl}
\hline Year Published & \multicolumn{1}{c}{ Regulation } \\
\hline 1970 s & Corporate Social Responsibility (CSR) \\
\hline 1991 & Corporate Behavior Charter \\
\hline 1991 & The Waste Disposal Law (amended in 2003) \\
\hline 2003 & Subcommittee on Socially Responsible Management \\
\hline 2004 & $\begin{array}{l}\text { infectious waste management (revised regulation including new criteria) } \\
\text { published by Ministry of Environment }\end{array}$ \\
\hline 2012 & $\begin{array}{l}\text { The Situation of Illegal Dumping of Industrial Waste by Ministry of } \\
\text { Environment }\end{array}$ \\
\hline 2013 & $\begin{array}{l}\text { The Emissions and Treatment of Industrial Waste by Waste Management and } \\
\text { Recycling Department, Ministry of Environment }\end{array}$ \\
\hline & $\begin{array}{l}\text { Report on Survey of Discharge and Disposal of Industrial Waste by Waste } \\
\text { Management and Recycling Department, Ministry of Environment }\end{array}$ \\
\hline
\end{tabular}

Concerns about packaging waste prompted the FPMAJ to form an investigational committee in July 2006 to address issues such as amending the Containers and Packaging Recycling Law, managing healthcare waste such as aerosol cans and self-injecting syringes, and revising the recycling symbol and push-out symbol on PTP (Press Through Pack) packaging for tablets and capsules. In February 2005, FPMAJ initiated the Healthcare Related General Waste Control Project. The FPMAJ and other interested parties collaborated to develop a method for properly disposing of expired injection needles, discarded medication, and aerosol medications. An annual follow-up session to the Nippon Keidanren's Environment Voluntary Action Plan is also held. The sessions held under this initiative are open to Japan Pharmaceutical Manufacturers Association (JPMA) member companies and institutions that are members of FPMAJ. Pharmaceutical firms conduct a follow-up audit, compile and analyse data, and report the findings to FPMAJ (24). Up to now, Japan applies the WHO method and continues to develop rapidly by implementing other new methods, Japan's efforts to improve its management of industrial waste have been recognized internationally, and useful lessons can be drawn from them, namely 3R (reduce reuse recycle), updating regulations to hold waste generators responsible, voluntary measures for industries, market-based instruments to subsidize city-level action, and awareness-raising programmes were all part of the mix that helped change attitudes and practices in industrial waste management. The results were soon apparent: between 1990 and 2010 , landfill of industrial waste decreased by 84 per cent, while the resource productivity rate between 2000 and 2010 increased by 51 per cent. Japan's efforts to improve its management of industrial waste have been recognized internationally, and useful lessons can be drawn from them. All methods incineration, autoclaving, microwaving, chemical disinfection, deep burial, secure land filling, encapsulation, inertization, and sewer are applied in Japan (27). 


\section{Thailand}

The Royal Thai Government, which is divided into central, provincial, and local governments, is in charge of municipal solid waste (MSW) and industrial waste management in Thailand. Local governments are in charge of waste disposal in their jurisdiction.

Table 6. Waste Management Acts (29)

\begin{tabular}{cll}
\hline Year Published & \multicolumn{4}{l}{ Regulation } \\
\hline 1992 & Public Health Act. B.E.2535 & \\
\hline 1992 & $\begin{array}{l}\text { Enhancement and Conservation of National Environmental Quality } \\
\text { Act.B.E.2535 }\end{array}$ & \\
\hline 1992 & Industry Act \\
\hline 1992 & Factory Act \\
\hline 1953 & Municipality Act. B.E.2496 \\
\hline 1994 & Sub-District Council \& Local Administrative Organizations Act. B.E.2537 \\
\hline 1999 & $\begin{array}{l}\text { Provincial Administrative Organization Act. B.E.2542, Decentralization to } \\
\text { LAO Act. B.E.2542 }\end{array}$ \\
\hline 2011 & Occupational Safety, Health and Environment Act B.E 2554 \\
\hline & $\begin{array}{l}\text { Enhancement and conservation of national environmental quality act } \\
\text { amendment 2 }\end{array}$ \\
\hline
\end{tabular}

Local governments employ private companies that have been given permission by Thailand's Pollution Control Department (PCD) to dispose of waste such as Better World Green Public Company Limited (BGW), Bangpoo Industrial Waste Management Center, Waste Management Siam LTD (WMS), General Environmental Conservation Public Company Limited (GENCO), and SGS (formerly Société Générale de Surveillance) Thailand. Local governments are in charge of waste management (28). PCD (Pollution Control Department), under The Ministry of Natural Resource and Environment (MONRE) is managing waste management in Thailand. Some of the Waste Management Acts that have been enforced by local governments are listed in Table 6. The WHO guideline is quite relevant and all methods are suitable to be applied, but still need improvement on developing and implementing new methods (4). All methods incineration, autoclaving, microwaving, chemical disinfection, deep burial, secure land filling, encapsulation, inertization, and sewer are applied in Thailand.

\section{China}

In China, the Health Bureau, the Urban Management Bureau, and the Environmental Protection Agency are in charge of waste management The Health of Bureau is primarily responsible for managing disease prevention in the entire phase of medical waste, as well as the preparation of a Medical Waste Management contingency plan; The Environmental Protection Bureau is primarily responsible for managing pollution prevention and control; the Urban Management Bureau is responsible for managing medical waste safely. Medical waste disposal centre (such as Yuri International Environmental Science and Technology Company in Xinxiang) are in charge of the timely processing, storage, and safe disposal of medical wastes, as well as the planning of medical waste disposal in accordance with emergency response plans. Special administration divisions, such as the Medical Policy Department (in the Health Bureau) and Solid Waste Management, have been developed to increase the efficiency of waste management. Quantitative and assessment rules, a macro-control framework, a 
management database interface, and a recycling network in remote areas are among the initiatives that have been implemented (30). Indonesia, India, Japan, Thailand, and China have implemented pharmaceutical industrial waste management that follows the regulation of their respective countries. The techniques used in handling waste is similar to the WHO guideline. It is obliged to report the results of processing and inspection of waste produced from the pharmaceutical industry.

Table 7. China Waste Regulation (31)

\begin{tabular}{ll}
\hline Year Published & \multicolumn{1}{c}{ Regulation } \\
\hline Amended 2017 & Waste Disposal Act (Environmental Protection Adm.) \\
\hline Amended 2013 & Pharmaceutical Good Manufacturing Practice Regulations \\
\hline Amended 2020 & Standards for Defining Hazardous Industrial Waste \\
\hline Amended 2021 & $\begin{array}{l}\text { Methods and Facilities Standards for the Storage, Clearance and Disposal of } \\
\text { Industrial Waste }\end{array}$ \\
\hline
\end{tabular}

China is a country that has implemented the WHO method and developed the method with renewable technology (14).

\section{Conclusion}

Pharmaceutical waste management in five countries has been implemented following the regulations of their own country. Each country has its own additional requirements on how the waste management. There is minor differential regulation in each country such as waste classification and waste treatment facilities (public and/or private). Some factors affecting the country regulations are the insufficient of land and waste management facilities, lack of awareness, low penalties, limited infrastructures, lack of waste testing facilities. The challenge in the future to handle pharmaceutical waste are increasing waste volume, decreasing land for waste management, sewer methods may contaminate water, possible air pollution due to incineration, so it is necessary to have more advanced methods in waste management that are safe for the environment and humans.

\section{References}

1. Oktem, Y.A., Ince, O., Sallis, P., Donnelly, T., Ince, B.K. Anaerobic treatment of a chemical synthesis-based pharmaceutical wastewater in a hybrid upflow anaerobic sludge blanket reactor. Bioresource Technology. 2008; 99(5) : 1089-1096.

2. World Health Organization. Safe management of wastes from health-care activities / edited by Y. Chartier et al. - 2nd ed. [Download on May 7, 2021]. Available at:

https://www.euro.who.int/_data/assets/p df_file/0012/268779/Safe-managementof-wastes-from-health-care-activitiesEng.pdf

3. World Health Organization. Guidelines for safe disposal of Unwanted Pharmaceuticals in and after Emergencies. [Download on May 7, 2021] Available at: https://www.who.int/water_sanitation_hea lth/medicalwaste/unwantpharm.pdf

4. Ferronato, N. and Torretta, V. Waste Mismanagement in Developing Countries: A Review of Global Issues. International Journal of Environmental Research and Public Health. 2019; 1:1060.

5. Babu, S.S., Chakrabarti, T., Bhattacharyya, J.K., Biswas, A.K., Kumar, S. Studies on environmental quality in and around municipal solid waste dumpsite. Resour. Conserv. Recycl. 2010; 55, 129 134. 
6. Parameswari, K., Padmini, T.K., Mudgal, B.V. Assessment of soil contamination around municipal solid waste dumpsite. Indian J. Sci. Technol. 2015; 8:36.

7. Kanmani, S., Gandhimathi, R. Assessment of heavy metal contamination in soil due to leachate migration from an open dumping site. Appl. Water Sci. 2012; 3: 193-205.

8. Prechthai, T., Parkpian, P., Visvanathan, C. Assessment of heavy metal contamination and its mobilization from municipal solid waste open dumping site. J. Hazard. Mater. 2008; 156: 86-94.

9. Thongkamsuk, P., Sudasna, K., Tondee, T. Waste generated in high-rise buildings construction: A current situation in Thailand. Energy Procedia. 2017; 138: 411-416.

10. Kofoworola, O.F., Gheewala, S.H. Estimation of construction waste generation and management in Thailand. Waste Manag. 2009; 29: 731-738.

11. Del Río Merino, M., Gracia, P.I., Azevedo, I.S.W. Sustainable construction: Construction and demolition waste reconsidered. Waste Manag. Res. 2010; 28: 118-129.

12. Mmereki, Daniel, Baldwin, A., Hong, L., and Li, B. The Management of Hazardous Waste in Developing Countries, Management of Hazardous Wastes, Edited by Hosam El-Din M Saleh and Rehab O. Abdel Rahman. 2016. IntechOpen.

13. World Health Organization. Safe Management of Wastes from Health-Care Activities. 1999. Geneva: WHO.

14. Ministry of Environment and Forests. Report of the Committee to Evolve Road Map on Management of Wastes in India. [Download on May 8, 2021] Available at: https://www.nswai.org/docs/RoadmapMgmt-Waste.pdf
15. Central Pollution Control Board (CPCB). Guidelines for Common Bio-medical Waste Trestment Facilities. [Accessed on May 8, 2021]. Available at: https://cpcb.nic.in/bio-medical-wasterules/

16. Government Regulation of the Republic of Indonesia Number 101 of 2014 concerning Management of Hazardous and Toxic Waste. Jakarta, Government of the Republic of Indonesia.

17. World Health Organization. Global Healthcare Waste Project Module 15: NonIncineration Treatment and Disposal of Healthcare Waste. WHO-UNDP. [Download on July 1st, 2021] Available at: https://www.who.int/water_sanitation_hea 1th/healthcare_waste/module15.pdf

18. Regulation of The Minister of Environment and Forestry of The Republic of Indonesia Number 56 of 2015 concerning Procedures and Technical Requirements of Hazardous Waste Management from Health Facilities. Jakarta, Ministry of Environment and Forestry

19. Documentation and Legal Information Network of The Ministry of Environment and Forestry of The Republic of Indonesia [Accessed on May 7, 2021] Available at: http://jdih.menlhk.co.id/

20. Regulation of the State Minister for the Environment of the Republic of Indonesia Number 16 of 2012 concerning Guidelines for the Preparation of Environmental Documents. Jakarta, Ministry of Environment.

21. Regulation of the Minister of Environment of the Republic of Indonesia Number 5 of 2014 concerning Wastewater Quality Standards. Jakarta, Ministry of Environment. 
22. Chakraborty P. Indian Pharmaceuticals Industry in Global Scenario: An Appraisal. Journal of Health Management. 2020; 22(3): 424-429.

23. Central Pollution Control Board (CPCB): Rules. [Accessed on May 7, 2021]. Available at: https://cpcb.nic.in/rules/

24. Hiroshi H., Nippon Keidanren's Subcommittee on Socially Responsible Management. Corporate Social Responsibilty: The Strength of Japanese Corporations. [Accessed on May 8, 2021]. Available at: https://www.keidanren.or.jp/english/polic y/csr/economic-trend_200411_p60

25. Miyazaki $M$, Une $H$. Infectious waste management in Japan: a revised regulation and a management process in medical institutions. Waste Manag. 2005;25(6):616-621.

26. Ministry of the Environment Government of Japan. Recycle Waste. [Accessed on July 1st, 202] Available at: http://www.env.go.jp/recycle/waste/sangy $\underline{\text { o.html }}$
27. United Nation Environment Programme. The Japanese Industrial Waste Experience: Lessons for Rapidly Industrializing Countries. 2013. Japan: UNEP.

28. Jiaranaikhajorn, T. Waste and Hazardous Substances Management Bureau. Thailand, Pollution Control Department (PCD).

29. Kamuang, T. and Siriatpiriya, O. Thailand, Country Chapter, State of the 3Rs in Asia and the Pacific. United Nations Centre for Regional Development; 2018 January; Thailand. Thailand: Chulalongkorn University; 2018.

30. Nie, L., Qiao, Z., and Wu, H. Medical Waste management in China: A Case study. Journal of Environmental Protection. 2014; 5: 803-810.

31. Ministry of Justice. Laws and Regulations Database of The Republic of China. [Accessed on May 7, 2021] Available at: https://law.moj.gov.tw/ENG/Law/LawSea rchLaw.aspx 